\title{
The Workplace Stress and its Related Factors among Indonesian Academic Staff
}

\author{
Nina Dwi Lestari, Nur Rizkiyah \\ Department of Community, School of Nursing, Faculty of Medicine and Health Sciences, Universitas Muhammadiyah
} Yogyakarta, Bantul, Indonesia

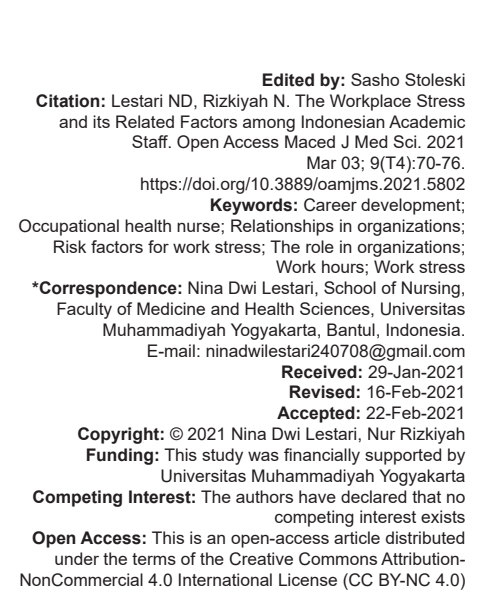

\begin{abstract}
BACKGROUND: Work stress has severe implications for employee health and the economy. It not only increases anxiety and depression but it also leads to an estimated $50 \%$ increase in the risk of heart disease, significant economic consequences, partly through the costs to employers of sickness, absence, and the costs to wider society of treating the health illness. It is essential for the nurse to identify the risk factors related to work stress and to make possible ways of reducing it.

AIM: This study aims to determine the factors associated with work stress in academic staff. The samples were 76 academic staffs at Universitas Muhammadiyah Yogyakarta.

METHODS: The samples were taken by simple random sampling technique. The instrument used was a work stress questionnaire from National Institute for Occupational Safety and Health that had been modified and a stress factor questionnaire. The analysis statistic was used Spearman rank.

RESULTS: This study showed that most respondents had a moderate work stress level $(72.4 \%)$. The factors affecting work stress were the length of work $(p=0.002)$, the role of individuals in the organization $(p=0.026)$, career development $(p=0.027)$, and relations in the organization $(p=0.03)$.

CONCLUSION: There was no relationship between working hours with the work stress level $(p=0.148)$. It needs more reliable monitoring of stress levels and improvements in work organization to reduce stress risks as far as possible, by improvements in job design, forms of support, and higher levels of employee involvement.
\end{abstract}

\section{Introduction}

The number of workers in the world reached $3,305,337,000$ people in 2018. The number of Indonesian workers increased by $1.79 \%$ in January 2018 from 131.55 million to 133.94 million workers [1]. The increase in workers is followed by an increase in health problems resulting from potential workplace hazards [2]. One of the working risk potentials that lead to personal and psychological risks is stress caused by work [3].

Job stress is experienced by workers who encounter an imbalance between physical and psychological [4]. Previous research related to work stress in education personnel showed that teachers who experienced work stress were $12.5 \%$ in the light category, $81.3 \%$ in the moderate category, and $6.3 \%$ in the heavy category [5].

Stress can be caused by several factors, namely, the role of individuals in the organization, career development, work relationships, and intrinsic factors in work. Not all workers can implement their respective roles in their workplace, which will result in role conflicts that can cause work stress. A person who does not have the opportunity to develop a career, such as using job skills and developing new skills, can be at risk of experiencing job stress [6]. Problems in organizational relationship such as poor relationships in organization or workplace, low trust, and low interest in problem solving in organization or workplace are also significantly at risk of creating work stress [7]. The intrinsic factor in covering working hours, years of work, and excessive workload are hazardous to cause work stress [6]. The excessive pressure at work can trigger work-related stress [8].

The maladaptive stress response results in adverse effects such as decreased health, work productivity, and income [9]. Stress in the moderate-tosevere category will result in a drastic decrease in work, errors in solving problems, difficult sleeping, blood pressure increase, spinal disorders, and digestive disorder experience [10]. Stress in heavy categories may increase cardiovascular diseases and disorders, especially spinal bone [11].

Occupational health nurses (OHNs) have a role in promoting preventive and rehabilitative efforts to improve and maintain health from occupational accidents 
and hazard risk factors in the workplace [12]. OHN is a registered nurse who can independently observe and conduct an assessment of workers' health related to the work they do, the danger, and the risk in their workplace [13]. In carrying out preventive efforts, OHN can identify risk factors for workers' work stress [12].

Based on the result of a preliminary survey conducted at the Bureau of Human Resources at Universitas Muhammadiyah Yogyakarta, it was found that the regulation of the employee working hours per day is $8 \mathrm{~h}$, but in implementation, it can be more than $8 \mathrm{~h}$. There is a sense of discomfort due to differences in working tenure. The work period affects how much workload received. The employees with long working tenure also get a high workload as they are believed to be able to complete work according to their work experience. Based on the background description above, it can be seen that the administrative staff at Universitas Muhammadiyah Yogyakarta is at risk of experiencing work stress. Therefore, the researcher would like to identify the factors that influence work stress on the administrative staff.

\section{Methods}

This research is quantitative correlation research with a population of 214 . This research sample was the administrative staff at the Muhammadiyah University of Yogyakarta, as many as 76 respondents who were taken by simple random sampling technique. The inclusion criteria of this study were such as willing to be respondents of this research, while the exclusion criteria were the respondents who did not return the questionnaire at the time of collecting data. The instruments used were a work stress questionnaire from the National Institute for Occupational Safety and Health Generic Job Stress modified by researchers and a stress factor questionnaire tested for validity and reliability on 30 people with characteristics similar to the sample used. The results of the validity test on the job stress questionnaire and stress factors were declared valid, with the value of $r$ count on the job stress questionnaire (0.385-0.700), the role of individuals in the organization (0.441-0.752), career development $(0.375-0.752)$, and relationships in organizations $(0.375-0.780)$. This questionnaire was also declared reliable with the Cronbach's alpha value for the job stress questionnaire, which was 0.768; the role of individuals in the organization (Cronbach's alpha 0.698), career development (Cronbach's alpha $0.726)$, and the organizational relations questionnaire (Cronbach's alpha 0.752). The statistical test in this study used the Spearman rank test. This research had undergone ethical clearance with letter number 012/ EC-KEPKFKIKUMY/I/2020.

\section{Results}

\section{Characteristics of respondents}

The respondents' characteristics showed that most of the respondents aged $21-40$ years old $(73.7 \%)$ were female (55.3\%). Most of the respondents' last education level was undergraduate $(76.3 \%)$, and most of the respondents had an income below the regional income standard (63.2\%) (Table 1).

Table 1: Distribution of characteristics of the respondent in February $2020(n=76)$

\begin{tabular}{lll}
\hline Characteristics & Frequency & Percentage \\
\hline Age & & \\
$\quad$ Early adult: & 56 & 73.7 \\
$\quad 21-40$ & & \\
$\quad$ Late adult: $41-60$ & 20 & 26.3 \\
$\quad$ Sex & & \\
$\quad$ Male & 34 & 44.7 \\
$\quad$ Female & 42 & 55.3 \\
Education degree & 15 & 19.7 \\
$\quad$ High school & 3 & 3.9 \\
$\quad$ Diploma & 38 & 76.3 \\
$\quad$ Bachelor & & \\
Salary & 48 & 63.2 \\
$\quad<1.649 .800$ (IDR) & 28 & 36.8 \\
$\quad \geq 1.649 .800$ (IDR) & & \\
\hline Source: Primary data, 2020. & &
\end{tabular}

\section{Work stress and its variables}

The univariate analysis showed that most of the respondents experienced work stress in the moderate category $(72.4 \%)$ and worked more than $8 \mathrm{~h}$ $(55.3 \%)$. Most of the respondents were included in new workers or $<6$ years $(60.5 \%)$ of working experience. The analysis of statistics about the role of respondents in their organization or workplace showed that they were mostly in the moderate category $(68.4 \%)$, had sufficient career development opportunities (68.4\%), and had relationships in organizations or workplace institutions in the moderate category (78.9\%). There were no respondents who had a good category in organizational relations (Table 2 ).

Table 2: Univariate analysis of work stress and its variables in February $2020(n=76)$

\begin{tabular}{|c|c|c|}
\hline Variables & Frequency & Percentage \\
\hline \multicolumn{3}{|l|}{ Work stress category } \\
\hline Mild & 8 & 10.5 \\
\hline Moderate & 55 & 72.4 \\
\hline Severe & 13 & 17.1 \\
\hline \multicolumn{3}{|l|}{ Work time category } \\
\hline No risk ( $\leq 8 \mathrm{~h})$ & 34 & 44.7 \\
\hline Risk (>8 h) & 42 & 55.3 \\
\hline \multicolumn{3}{|l|}{ Work tenure category } \\
\hline Old (>10 years) & 21 & 27.6 \\
\hline Moderate (6-10 years) & 9 & 11.8 \\
\hline New ( $<6$ years) & 46 & 60.5 \\
\hline \multicolumn{3}{|l|}{ Individual role category } \\
\hline Good & 16 & 21.1 \\
\hline Enough & 52 & 68.4 \\
\hline Poor & 8 & 10.5 \\
\hline \multicolumn{3}{|c|}{ Career development opportunities category } \\
\hline Good & 7 & 9,2 \\
\hline Enough & 58 & 76.3 \\
\hline Poor & 11 & 14.5 \\
\hline \multicolumn{3}{|c|}{ Relationship in organization category } \\
\hline Good & 0 & 0 \\
\hline Enough & 60 & 78.9 \\
\hline Poor & 16 & 21.1 \\
\hline
\end{tabular}




\section{work stress}

\section{Relationship between work tenure and}

Table 3 provides information that respondents who had worked in the new, medium, and old categories all had work stress in the moderate category, namely, $40.8 \%, 10.5 \%$, and $21.1 \%$. There was a significant relationship between tenure and the onset of work stress with $p=0.002(p<0.05)$ with a correlation coefficient $(R)$ of 0.34 or had a low relationship.

Table 3: Relationship between work tenure and work stress of respondents in February $2020(n=76)$

\begin{tabular}{|c|c|c|c|c|c|c|c|}
\hline \multirow[t]{3}{*}{ Work stress } & \multicolumn{6}{|c|}{ Work tenure } & \multirow[t]{3}{*}{$p$-value } \\
\hline & \multicolumn{2}{|c|}{ New } & \multicolumn{2}{|c|}{ Moderate } & \multicolumn{2}{|c|}{ Old } & \\
\hline & $\mathrm{F}$ & $\%$ & $\mathrm{~F}$ & $\%$ & $\mathrm{~F}$ & $\%$ & \\
\hline Mild & 3 & 3.9 & 0 & 0 & 5 & 6.6 & 0.002 \\
\hline Moderate & 31 & 40.8 & 8 & 10.5 & 16 & 21.1 & \\
\hline Severe & 12 & 15.8 & 1 & 1.3 & 0 & 0 & \\
\hline Total & 46 & 60.5 & 9 & 11.8 & 21 & 27.6 & \\
\hline
\end{tabular}

Source: Primary data, 2020

\section{Relationship between working hours per day and work stress}

Table 4 shows that most respondents who had a working duration of more than $8 \mathrm{~h}$ per day or $\leq 8 \mathrm{~h}$ per day had work stress in the moderate category. There was no relationship between the duration of work time per day and work stress with $p=0.148$ ( $p \geq 0.05)$.

Table 4: Relationship between working hours per day and work stress in February 2020 ( $n=76)$

\begin{tabular}{|c|c|c|c|c|c|}
\hline \multirow[t]{3}{*}{ Work stress } & \multicolumn{4}{|c|}{ Work tenure } & \multirow[t]{3}{*}{$\mathrm{p}$-value } \\
\hline & \multicolumn{2}{|c|}{$<8 \mathrm{~h}$} & \multicolumn{2}{|c|}{$>8 \mathrm{~h}$} & \\
\hline & $\mathrm{F}$ & $\%$ & $\mathrm{~F}$ & $\%$ & \\
\hline Mild & 4 & 5.3 & 4 & 5.3 & 0.148 \\
\hline Moderate & 27 & 35.3 & 28 & 36.8 & \\
\hline Severe & 3 & 3.9 & 10 & 13.2 & \\
\hline Total & 34 & 44.7 & 42 & 55.3 & \\
\hline
\end{tabular}

Relationship between respondents' role in organization (working institution) and work stress

Table 5 shows that respondents who had a good, adequate, and insufficient role in work institutions all had moderate work stress. The results of the Spearman rank test showed $p=0.026(p<0.05)$, indicating that there was a significant relationship between the role of the respondent in the organization (work institution) and work stress.

Table 5: Relationship between respondents' role in organization (working institution) and work stress

\begin{tabular}{|c|c|c|c|c|c|c|c|}
\hline \multirow[t]{3}{*}{ Work stress } & \multicolumn{6}{|c|}{ Work tenure } & \multirow[t]{3}{*}{$\mathrm{p}$} \\
\hline & \multicolumn{2}{|c|}{ Good } & \multicolumn{2}{|c|}{ Enough } & \multicolumn{2}{|c|}{ Poor } & \\
\hline & $\mathrm{F}$ & $\%$ & $\mathrm{~F}$ & $\%$ & $F$ & $\%$ & \\
\hline Mild & 1 & 1.3 & 6 & 7.9 & 1 & 1.3 & 0.026 \\
\hline Moderate & 15 & 19.7 & 38 & 50 & 2 & 2.6 & \\
\hline Severe & 0 & 0 & 82 & 10.5 & 5 & 6.6 & \\
\hline Total & 16 & 21 & 52 & 68.4 & 8 & 10.5 & \\
\hline
\end{tabular}

Relationship between career development opportunities and work stress

Table 6 shows that respondents had the opportunity for career development in good, fair, or bad categories. The majority of respondents had work stress in the moderate category, namely, 6.6\%, 57.9\%, and $7.9 \%$, respectively. $p=0.027(p<0.05)$ revealed that there was a significant relationship between career development opportunities and work stress.

Table 6: Relationship between career development opportunities and work stress in February $2020(n=76)$

\begin{tabular}{|c|c|c|c|c|c|c|c|}
\hline \multirow[t]{3}{*}{ Work stress } & \multicolumn{6}{|c|}{ Work tenure } & \multirow[t]{3}{*}{$p$-value } \\
\hline & \multicolumn{2}{|c|}{ Good } & \multicolumn{2}{|c|}{ Enough } & \multicolumn{2}{|c|}{ Poor } & \\
\hline & $F$ & $\%$ & $\mathrm{~F}$ & $\%$ & $F$ & $\%$ & \\
\hline Mild & 1 & 1.3 & 7 & 9.2 & 0 & 0 & 0.027 \\
\hline Moderate & 5 & 6.6 & 44 & 57.9 & 6 & 7.9 & \\
\hline Severe & 1 & 1.3 & 7 & 9.2 & 5 & 6.6 & \\
\hline Total & 7 & 9.2 & 58 & 76.3 & 11 & 14.5 & \\
\hline
\end{tabular}

The correlation between relationship in organization (working institution) and work stress

Table 7 shows that all respondents had sufficient and bad relationships within the organization. Both of them had a moderate work stress category, with the respective percentages of $60.5 \%$ and $11.9 \%$. $p=0.03(p<0.05)$ indicating that there was a significant relationship between the relationship in the organization or work institution and the onset of work stress with an R-value of 0.25 .

Table 7: The correlation between the relationship between an organization (working institution) and work stress in February $2020(n=76)$

\begin{tabular}{|c|c|c|c|c|c|c|c|}
\hline \multirow[t]{3}{*}{ Work stress } & \multicolumn{6}{|c|}{ Work tenure } & \multirow{3}{*}{$p$-value } \\
\hline & \multicolumn{2}{|c|}{ Good } & \multicolumn{2}{|c|}{ Enough } & \multicolumn{2}{|c|}{ Poor } & \\
\hline & $\mathrm{F}$ & $\%$ & $F$ & $\%$ & $F$ & $\%$ & \\
\hline Mild & 0 & 0 & 7 & 9.2 & 1 & 1.3 & 0.03 \\
\hline Moderate & 0 & 0 & 46 & 60.5 & 9 & 11.9 & \\
\hline Severe & 0 & 0 & 7 & 9.2 & 6 & 7.9 & \\
\hline Total & 0 & 0 & 60 & 78.9 & 16 & 21 & \\
\hline
\end{tabular}

Source: Primary DATA, 2020

\section{Discussion}

\section{Description of respondent characteristics}

The statistical tests in Table 1 showed that most of the respondents were $21-40$ years old $(73.7 \%)$. Workers aged 21-40 years old were more at risk of experiencing work-related stress as they were exposed to more nervous tension. The previous studies showed that 21-40-year-old workers experienced more severe stress than respondents aged 41-60 years old [14]. Nervous tension created severe stress in employees aged 21-40 years old due to inexperienced and improper coping mechanisms [15].

Based on gender characteristics, most of the respondents were female $(55.3 \%)$. Women are more at risk of experiencing work stress due to the changing hormones estrogen and progesterone so that women's emotions become unstable. Harsh working conditions can exacerbate this condition so that women feel more depressed, causing stress [16]. Women's dual role as workers and homemakers can lead to overexertion, which risks causing psychological distress or stress [17]. 
Based on Table 1, the education level of the respondents was mostly undergraduate (76.3\%). Higher education levels will decrease the risk of work stress compared to workers with low education. It could happen as the higher education of the people could increase their thinking ability. The higher the level of education and knowledge of the workers could make them able to do the assigned task better [18]. The lower education workers have difficulty absorbing information and implementing it daily while they work [19].

The respondents' income description presented in Table 1 showed that most respondents had an income less than the regional standard (63.8\%). It raises workers' dissatisfaction with the salary they have been received and makes it insufficient to meet their daily needs [20]. The inadequate salary was associated with the incidence of workplace stress $(p=0.001)$ [17].

\section{Description of job stress}

Based on the research results in Table 2, respondents who experienced stress due to the high working category were 13 respondents. Work stress will affect employees' performance, health, and accuracy in doing their work tasks. Some of the factors that can cause stress due to work are excessive working hours and work relationships. Administrative employees had working hours that were not in accordance with the rules, which should only be $8 \mathrm{~h}$. Based on research conducted by Purnama et al. [21], the factors that could cause work stress other than the above were mental workload, work routine, and personality type.

\section{in 1 week \\ Description of the average working hours}

The results showed that the average working hours in 1 week were mostly $>8 \mathrm{~h}$ as many as 42 respondents (Table 2). Respondents who had working hours $>8 \mathrm{~h}$ will be more at risk of experiencing stress because respondents must immediately complete work tasks received according to predetermined targets and deadlines. Respondents who have close deadlines will have working hours $>8 \mathrm{~h}$ to trigger work stress [8]. It is supported by research conducted by Wachs [22] that excessive working hours would have an impact on work stress due to a lack of time management and work strategies.

\section{employees \\ Description of tenure of administrative}

The research results showed that most of the employees had a new tenure $(60.5 \%)$. Most of the new employees were 21-40 years old (Table 3). Early adulthood employees tended to have not much work experience, resulting in them experiencing work stress [23]. The new work period could affect the time for completing the employees' work tasks due to fewer work experiences. They were more likely to experience work-related stress than employees with long tenure. New tenure tends to respond negatively to work pressure due to the inability to adapt to the new work environment and the lack of experience that the employees have [24].

\section{Description of the role of individuals} in the organization, career development, and relationships in the organization to administrative employees

This study indicated that most of the employees were in the sufficient category in individual roles in the organization, career development, and relationships in the organization as many as 52,58 , and 60 employees (Table 2), respectively. The role of individuals in a bad organization will trigger stress due to work on employees. It is because the employee experiences role coercion [25]. Most of the career development in this research was in a sufficient category. Seven respondents with the career development category experienced enough stress due to the heavy work category. The worse the employee's career development, the worse the employee's work stress [21].

Apart from individual roles and career development, employee organizations' relationships were mostly in the moderate category. In this study, there were no employees who had good relationships in the organization. It could be due to the bad relationship between colleagues and superiors, lack of trust between colleagues in fulfilling responsibility, and the absence of positive feedback [7].

\section{work stress}

\section{Relationship between work period and}

Based on Table 3, respondents with a new tenure experienced more stress due to the heavy work category, namely, 12 employees, compared to respondents with a long working period. The significance test value of $0.002(p<0.05)$ indicated a significant relationship between tenure and work stress. The correlation coefficient value was 0.345 , indicating that the strength of the relationship between tenure and work stress was low and had a positive direction. It meant that newer employees could potentially get a higher risk of experiencing work stress. It was because employees with new tenure had a higher risk of experiencing work stress than employees with long tenure. Some of the factors that made the new work period more susceptible to stress were lack of work experience in the current job, difficulty adapting to a new work environment, and difficulty completing work tasks and disobedience to work methods so that they are unable to complete work tasks. 
This study's results are in line with research conducted by Saidah et al. [26], revealing that there was a relationship between work tenure and workinduced stress. The employee's newer tenure leads to arising work stress. Employees with younger years of work experience encountered severe stress as they tended to be less experienced, so they have difficulty dealing with new working and work environments. New employees have a higher risk of experiencing work stress than old employees [27].

\section{work stress}

\section{Relationship between working hours and}

Table 4 shows no relationship between working hours and work-induced stress with $p=0.148$ $(p>0.05)$. There was flexibility in working time so that employees who had other responsibilities outside the office were allowed to get permission and then returned to continue their work tasks even though they had more than $8 \mathrm{~h}$ of working hours.

The flexibility of working hours still used the standard minimum working hours of $8 \mathrm{~h}$. However, if an employee wanted to rest or travel, other employees would have to stand by to continue other activities [28]. It made the employees who got flexibility in working hours experienced less stress even though they had more than $8 \mathrm{~h}$ of work. Based on the research results conducted by Nursetyaningsih [29], employees who worked at night were more likely to experience work stress as working at night caused fatigue and sleepiness so that employee concentration decreased and work was not completed correctly and triggered work-induced stress.

\section{The relationship between the role of} individuals in organizations and work-related stress

Based on the bivariate test results in Table 5, there was a relationship between individuals' role in the organization and work stress $(p=0.026)$. Questionnaire analysis showed that $26.9 \%$ of respondents stated that they must continue their work that was not the employee's responsibility. It made them feel that their work was not based on their rules and triggered their work stress level.

The results of this study are in line with research conducted by Irzal [30], stating that the role of individuals in the organization was related to work-induced stress due to unclear roles, job dissatisfaction due to mistargeting, and doing tasks that were out of their field which resulted on workers confusion in carrying out their roles. It is also supported by the research conducted by Amalina et al. [31], stating that the factors of individual roles in organizations were related to work-induced stress due to role conflicts. Therefore, there was a mismatch of work tasks obtained and role coercion, which made the employees confused in carrying out their duties. In addition, the employees' lack of understanding of the work tasks and the increasing roles of employees could lead to work stress [27].

\section{The relationship between career development and job stress}

The bivariate analysis result showed a relationship between career development and work stress with $p=0.027$. The career development questionnaire analysis showed that $30.8 \%$ of respondents stated that they were not satisfied with promotion opportunities at work. There were $32.1 \%$ of unsatisfied respondents.

This study's results align with the other research results [27], which stated that career development had a significant relationship to workinduced stress. It was explained that poor career development was caused by a lack of job promotion and inadequate daily life wages. The lack of salaries related to the short contract employment status made the employees' salaries smaller than employees who had been already become civil servant officers/ permanent contract officers, even though the workload received was the same. Meanwhile, it is also supported by the research conducted by Purnama et al. [21], revealing that career development would be a trigger for work-related stress if the employee thought that the salary received was too low and caused dissatisfaction. The employee expectations at work were career advancement. However, their expectations frequently did not meet reality due to unclear career development, performance appraisal systems, and the absence of promotion opportunities, which could trigger employees to become stressed [32].

\section{Correlation between the relationship in the} organization and work stress

The bivariate test results in Table 7 showed that $p=0.03$ and $r=0.249$ were considered. It indicated that there was a relationship between the relationship in the organization and work stress with a positive $r$ value. The worse category of relationships in the organization led to the respondent's higher possibility of experiencing work stress with a heavy category. The organization's relationship was bad as they had disputes between colleagues in other units and problems with superiors. The disputes between coworkers and superiors will impact distrust in delegating heavy work and a lack of positive feedback from coworkers who were given responsibility. Moreover, the distrust between coworkers and superiors will make employees reluctant to experience problems and difficulties at work. It could trigger work stress on employees.

This study's results align with the research from Irzal [30] which stated that there was a relationship 
between organizational relationships and workinduced stress. Relationships in organizations are social relationships that exist between employees, either colleague, subordinate, or superior. Inadequate relationships in organizations will be a factor in causing work stress. The sign of a bad relationship in the organization is the suspicion of fellow employees, discomfort at work, and less communication resulting in less cooperation so that work completion takes longer. A mismatch with coworkers will also affect performance and cause work stress due to inoptimal cooperation [33].

\section{Conclusion}

Work stress had severe implications for employees' health and economic status. The factors affecting work stress were the length of work, the role of individuals in the organization, career development, and the organization's relationship. $\mathrm{OHN}$ is encouraged to do work stress prevention by minimizing the factors that affect it.

\section{Acknowledgments}

We wish to thank for all participants in this research. We would like to thank for Universitas Muhammadiyah Yogyakarta for funding this research.

\section{References}

1. Rahmawati F, Ekawati E, Kurniawan B. The relationship of noise and work shift to the level of work stress on the workers of the SWD (stork werkspoor diesel) PLTD Gunung Malang Balikpapan. J Kesehatan Masyarakat. 2017;5(5):156-62. https:// doi.org/10.38165/jk.v7i1.116

2. Setyadewi W. Pengaruh Senam Qigong Terhadap Tingkat Stres Kerja Pada Guru. (Unpublished Undergraduate Thesis). 2019. Bantul: Universitas Muhammadiyah Yogyakarta.

3. Febriandini AE, Ma'rufi I, Hartanti RI. Analysis of Individual Factors, Organizational Factors and Work Fatigue Against Job Stress in Nurses: A Study in a Class III Inpatient Room at dr. $\mathrm{H}$. Koesnadi, Bondowoso Regency. e-J Pustaka Kesehatan. 2016;4(1):175-80. https://doi.org/10.35800/jjs.v10i2.26751

4. Mayang S, Lestantyo D, Kurniawan B. Factors Related to Job Stress in Employees at the Ungaran Health Social Insurance Administration at Ungaran. J Kesehatan Masyarakat. 2018;6(4):292-9. https://doi.org/10.38165/jk.v6i1.137

5. Siregar RP. Pengaruh Stres Kerja dan Beban Kerja Terhadap Kinerja Karyawan Pada PT. Bank SUMUT (Kantor Cabang) Sukaramai Medan. (Unpublished Undergraduate Thesis). 2018. Indonesia: Universitas Muhammadiyah Sumatera Utara Medan. https://doi.org/10.30596/maneggio.v3i1.4834
6. Martiana T, Ansori R. The Relationship between Individual Characteristics and Work Conditions on Job Stress in Dental Nurses. Indones J Public Health. 2017;12(1):75-84. https://doi. org/10.20473/ijph.v12i1.2017.75-84

7. Stuart GW. Principles and Practice of Psychiatric Nursing. $10^{\text {th }}$ ed. Philadelphia, PA: Elsevier Mosby; 2014.

8. Suci IS. Analysis of the relationship between individual factors and mental workload with work stress. Int J Occup Saf Health. 2018;7(2):220-9. https://doi.org/10.20473/ijosh.v7i2.2018.220-229

9. Mochtar SM. Faktor yang berhubungan dengan Stres Kerja pada Pedagang Tradisional Pasar Daya Kota Makassar Tahun 2013. (Unpublished Undergraduate Thesis). Makassar: Universitas Hasanuddin; 2013.

10. Fatikhin F, Hamid D, Mukzam MD. The Effect of Work Conflict and Job Stress on Employee Performance (Study on Employees of PT. Bank Rakyat Indonesia (Persero) Branch Soekarno Hatta Malang). J Adm Bisnis. 2017;47(1):172-80. https://doi. org/10.31219/osf.io/rt3n4

11. Nurani PF, Wahyuni I, Jayanti S. Factors Related To Work Stress In Workers With Chemical Hazards In Limited Space At PT. Z. J Kesehatan Masyarakat. 2017;5(2):136-46. https://doi. org/10.37012/jik.v11i1.70

12. Handayani VN, Wahyuni I, Ekawati. Factors related to work stress in workers handling infrastructure and public facilities in West Jakarta: A case study in Kelurahan Pinangsia and Kelurahan Krukut, West Jakarta. J Kesehatan Masyarakat. 2019;7(4):463-8. https://doi.org/10.35880/inspirasi.v10i1.57

13. Hardy S. New Paradigm of Occupational Health Nursing Management in Community Nursing Learning. J Keperawatan. 2015;3(2):230-45.

14. Irkhami FL. Factors related to Work Stress in Divers at PT. X. Indones J Occup Saf Health. 2015;4(1):54-63. https://doi. org/10.20473/ijosh.v4i1.2015.54-63

15. International Labour Organization. Keselamatan dan Kesehatan Kerja Sarana Untuk Produktivitas (translated). Diakses Pada 6 Mei 2019 dari. Available from: https://www.ilo.org/jakarta/ whatwedo/publications/WCMS_237650/lang--en/index.htm. [Last accessed on 2019 May 06].

16. Widyastuti AD. The Relationship between Work Stress and Work Fatigue in the Box Truck Construction Workshop Area Workers. Indones J Occup Saf Health. 2017;6(2):216-24. https://doi.org/10.20473/ijosh.v6i2.2017.216-224

17. Setyowati A, Wahyuni I, Ekawati. The relationship between work organizational factors and workload on work stress on shipyard workers at PT. X. J Kesehatan Masyarakat. 2017;5(5):32-40. https://doi.org/10.29241/jmk.v6i2.338

18. Hasan A, Wahyuni I, Kurniawan B. Relationship between Mental Workload and Work Shift Against Work Stress in Central Control Room workers (Case Study at PT. PJB Unit Pembangkit Paiton Probolinggo). J Kesehatan Masyarakat. 2018;6(4):255-60. https://doi.org/10.30644/rik.v8i1.224

19. Muin M. Gambaran Tingkat Stress Kerja Pada Perawat D Pusat Kesehatan Masyarakat (PUSKESMAS) Kota Semarang. (Unpublished Doctoral Dissertation). Semarang: Universitas Diponegoro; 2017.

20. Kementerian Kesehatan Republik Indonesia. Hasil Utama Riskesdas 2018. Jakarta: Kementerian Kesehatan Badan Penelitian Dan Pengembangan Kesehatan; 2018. https://doi. org/10.31002/rep.v5i1.2050

21. Purnama KW, Wahyuni I, Ekawati. Factors related to work stress on civil servants of the Regional Disaster Management Agency (BPBD) Semarang City. J Kesehatan Masyarakat. 2019;7(4):246-53. https://doi.org/10.32672/makma.v2i2.1302

22. Wachs JE. The American association of ocupational health nurses seventy-five years of education, practice, and research. Workplace Health Saf. 2017;64(4):148-53. https://doi. org/10.1177/2165079917701139 
23. Manabung AR, South LF, Warouw F. Hubungan antara masa kerja dan beban kerja dengan stress kerja pada tenaga kerja $\mathrm{Di}$ PT pertamina TBBM bitung. J Kesmas. 2018;7:1-10. https://doi. org/10.29080/jhsp.v4i1.257

24. International Labour Organization. Employment To Population Ratio. Diakses pada 6 Mei 2019. International Labour Organization; 2018. Available from: https://www.ilo.org/ilostatfiles/Documents/description_EPR_EN.pdf. [Last accessed on 2019 May 06].

25. Lukas L, Suoth LF, Wowor R. The relationship between work environment temperature and working hours with work stress at PT. Adhi Karya (Persero) Tbk. The Manado unit of the Sam Ratulangi University project. J Kesma. 2018;7(4):1-9. https:// doi.org/10.31219/osf.io/k26hv

26. Saidah N, Ekawati, Widjasena B. Factors Associated with Work Stress on Room Administration Staff at RSUD K.R.M.T. Wongsonegoro Semarang City. J Kesehatan Masyarkat. 2018;6(2):94-102. https://doi.org/10.35747/hmj.v2i1.154

27. Sucipto CD. Keselamatan dan Kesehatan Kerja. Yogyakarta: Gosyen Publishing; 2014.

28. Fuada N, Wahyuni I, Kurniawan B. Factors Associated with Work Stress in Surgical Room Nurses at the Central Surgical
Installation of Rsud K.R.M.T Wongsonegoro Semarang J Kesehatan Masyarakat. 2017;5(5):255-63. https://doi. org/10.35747/hmj.v2i1.154

29. Nursetyaningsih DP. Hubungan Tuntutan Tugas, Tuntutan Peran, dan Tuntutan Antarpribadi Dengan Stres Kerja Pada Perawat Di Bagian IGD Rumah Sakit Haji Kota Makassar. Undergraduate Thesis Universitas Islam Negeri Alauddin Makassar; 2015. https://doi.org/10.24252/minds.v4i1.3135

30. Irzal. Dasar-Dasar Kesehatan dan Keselamatan Kerja. Jakarta: Kencana; 2016.

31. Amalina N, Huda BZ, Hejar AR. Job stress and its determinants among academic staff in university in Klang valley, Malaysia. Int J Sci. 2016;3(6):125-36.

32. Aiska S. Analisis Faktor-Faktor Yang Berpengaruh Pada Tingkat Stres Kerja Perawat di Rumah Sakit Jiwa Grhasia Yogyakarta. (Unpublished Undergraduate Thesis). Bantul: Universitas Muhammadiyah Yogyakarta; 2014. https://doi.org/10.35508/ tjph.v1i3.2136

33. Ferlia DA, Jayanti S, Suroto. Analysis of the Level of Job Stress on Tuna Grahita Teachers at the Purwosari Kudus State Primary School. J Kesehatan Masyarakat. 2016;4(3):331-41. https://doi. org/10.29240/bjpi.v2i1.270 